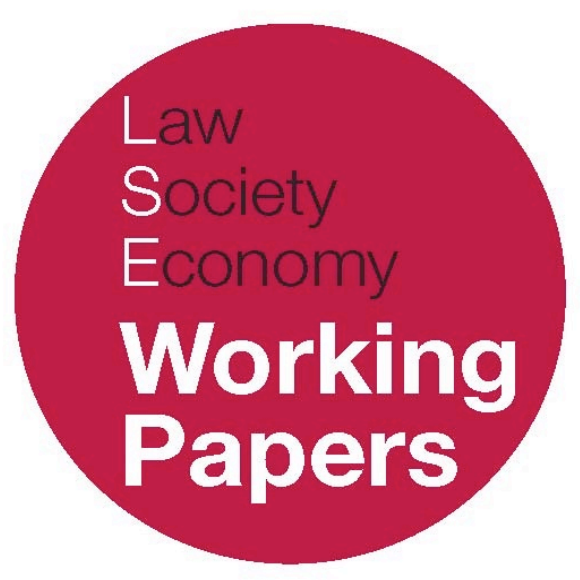

\title{
Norms, Normativity and the Legitimacy of Justice Institutions: International Perspectives
}

\author{
Jonathan Jackson \\ LSE Law, Society and Economy Working Papers 1/2018 \\ London School of Economics and Political Science \\ Law Department
}

\begin{abstract}
This paper can be downloaded without charge from LSE Law, Society and Economy Working Papers at: www.lse.ac.uk/collections/law/wps/wps.htm and the Social Sciences Research Network electronic library at: https://ssrn.com/abstract $=3129737$

(C) [Author]. Users may download and/or print one copy to facilitate their private study or for non-commercial research. Users may not engage in further distribution of this material or use it for any profit-making activities or any other form of commercial gain.
\end{abstract}




\title{
Norms, Normativity and the Legitimacy of Justice Institutions: International Perspectives
}

\author{
Jonathan Jackson ${ }^{*}$
}

\begin{abstract}
This article reviews the international evidence on the nature, sources and consequences of police and legal legitimacy. In brief, I find that procedural justice is the strongest predictor of police legitimacy in most countries, although normative judgements about fair process may - in some contexts - be crowded out by public concerns about police effectiveness and corruption, the scale of the crime problem, and the association of the police with a historically oppressive and underperforming state. Legitimacy tends to be linked to people's willingness to cooperate with the police, with only a small number of national exceptions, and there is fair amount of evidence that people who say they feel a moral duty to obey the law also tend to report complying with the law in the past or intending to comply with the law in the future. The main argument is, however, that international enthusiasm for testing procedural justice theory is outpacing methodological rigor and theoretical clarity. On the one hand, the lack of attention to methodological equivalence is holding back the development of a properly comparative cross-national analysis. On the other hand, the literature would benefit from (a) greater delineation between legitimation and legitimacy, (b) stronger differentiation between police and legal legitimacy, and (c) more attention given to isolating the mechanisms through which legitimacy motivates cooperation and compliance.
\end{abstract}

Keywords: compliance, policing, trust, law

\footnotetext{
* Department of Methodology, LSE.
} 


\section{INTRODUCTION}

The law is the most powerful tool available to government for the regulation of the behaviour of people with diverse values and interests. Legal authorities have an array of coercive powers to apprehend, prosecute and punish those who break the law, but as anyone who works in the criminal justice system knows, policing works best when it is not needed. Self-regulation is the most efficient, and least costly, route to rule-observance. Most self-regulation is shaped by forces that lie outside the ambit of the criminal justice system, as Robert Reiner notes in his classic book The Politics of the Police (2000: xi): '...subtle, informal social controls, and policing processes embedded in other institutions, regulate most potential deviance'.

Of course, legal authorities can - and do - play a role in encouraging people to self-regulate. On the one hand, coercive crime-control strategies seek to shift the incentive structures of autonomous rational choice actors: pro-active forms of policing and tough sentencing strategies hope to secure instrumental compliance, persuading people that the risks of criminal behaviour (particularly the certainty, severity and immediacy of punishment, Nagin, 2013) outweigh the benefits. On the other hand, consensual crime-control strategies seek to persuade people that the legal authorities are moral, just and entitled to be obeyed: process-based forms of policing hope to secure popular commitment to the law by treating people with fairness and dignity, making decisions in impartial and just ways, and respecting the limits of their own rightful authority. A key prediction of the most influential account of citizen-authority relations (procedural justice theory) is that people will comply with the law and cooperate with the legal authorities when they ascribe legitimacy to justice institutions (Tyler, 2006a, 2006b).

As debate continues about how best to design crime control-policy, there is a growing recognition among policy-makers in jurisdictions across the world that aggressive deterrence-based policing practices can backfire. By delegitimising legal authorities, they only increase the need for costly and minimally effective aggressive forms of crime-control (Tyler, 2003, 2004, 2011). Reflecting the increase in scholarly and policy interest into legitimacy and legitimation, the Annual Review of Law and Social Sciences has addressed the topic in both of the previous two editions. The 2016 edition saw Trinkner \& Tyler (2016) reviewing research on legitimacy, legal socialisation, and coercive and consensual authority-relations, while the 2017 edition contained a discussion of the observational flavour of the empirical evidence between Nagin \& Telep (2017a, 2017b) and Tyler (2017).

The current contribution adds to the debate by taking a distinctive look at the increasingly international nature of the research evidence. The path-breaking USbased work of Tyler and colleagues (Tyler, 1988, 1989, 1990, 1994, 1997; Sunshine \& Tyler, 2003; Tyler \& Huo, 2002; Tyler, 2006a, 2006b) has spread rapidly across the world, with studies being carried out in countries as diverse as Ghana, Finland, Russian Federation, the UK, Pakistan, Sweden, Japan, Israel, Australia, Turkey, South Africa, France, Ukraine, China and Nigeria. We have seen cross-national 
studies of police legitimacy covering 28 African countries (Boateng, 2017), 29 Asian countries (Boateng \& Buckner, 2017), and 27 European countries (Hough et al. 2013). Several edited book volumes have placed trust and legitimacy within broader societal contexts (Tyler, 2007; Tankebe \& Leibling, 2013; Meško \& Tankebe, 2014; Persak, 2016; Oberwittler \& Roché, 2017). In the most recent such volume, Oberwittler \& Roché (2017) brought together scholars from Europe, the US, Australia, Nigeria, Japan, Turkey and elsewhere, to examine the role that varying societal contexts and cleavages play in police-citizen relations.

This review focuses on the role that legitimacy plays in citizen-authority relations in diverse contexts. After sketching the broad contours of the legitimacy concept and the literature as a whole, it turns to the rapidly expanding body of research on police legitimacy. The focus is on the sources of police legitimacy and the extent to which legitimacy predicts people's willingness to cooperate with law enforcement officials. The review then considers legal legitimacy and its consequences for legal compliance. The paper finishes with some thoughts on how to enhance our ability to develop a properly comparative cross-national literature.

\section{SETTING THE SCENE \#1: WHAT IS (EMPIRICAL) LEGITIMACY?}

Political philosophers often employ legitimacy as a normatively-laden term to describe whether states and state institutions meet what Hinsch (2010: 41-42) calls 'certain substantive requirements - say, standards of justice and rationality expressed in a normative conception of legitimacy'. A standard Western account of the normative legitimacy of justice systems might, for instance, stress criteria like independence, transparency, consistency, respect for the rule of law, and so forth. On this account, for a society's court system to be judged as legitimate in the normative sense of the concept, it would need to have in place effective systems of due process, standards of accountability, oversight over sentencing and anticorruption safeguards. A defining feature of the normative concept is that what citizens think about their state institutions is not of central concern: normative legitimacy turns on what outside observers think about the ethical use of political power.

By contrast, social scientists often use legitimacy to describe whether - as a matter of fact - those that are subject to authority confer legitimacy on that authority (Tyler, 2006a, 2006b; Calderia \& Gibson, 1995; Gibson et al. 2003; Justice \& Meares, 2014; Meares, 2017). The empirical concept concerns the normative justification of power in the eyes of those who have to abide by that power structure. Legitimacy is premised on a "fundamental accord" between rulers and ruled (Filiangeiri 1783-88, in Pardo 2000: 5) that is founded in shared norms and values and established via the 'moral performance' (Liebling 2004) of power-holders. Applied to the police, this process involves acceptance (or rejection) of the implicit and explicit claims that 
police make to be a morally appropriate institution, leading to the presence (or absence) of voluntary deference to authority. Unlike the normative concept, it is those who are subject to - and the beneficiaries of - power who decide the criteria for the ethical use of political power, judging the legitimacy of the police against societal norms of appropriate conduct (Trinkner \& Tyler, 2016; Tyler \& Trinkner, 2018).

There are at least three distinctive features of legitimacy judgements in the context of legal institutions. Each references the power and authority connected to an institution:

1. right to power: citizens judge the normative justifiability of the power of a justice institution (based on the judgements of the overall appropriateness of the use of power);

2. authority to govern: citizens internalise a duty to obey the commands, rules and laws connected to a justice institution that they believe is moral, just and appropriate; and,

3. normative motivation: legitimacy influences behaviour via positive and negative duties and obligations.

On this account, when citizens view legal authorities as legitimate (i.e. when they are seen to have the right to power and the authority to govern) they are (a) motivated to comply with the rules and orders that emanate from the institution, and (b) motivated to proactively cooperate with the goals of that institution (e.g. come forward to report crimes, provide information to the police, and give evidence in court). They feel a normatively grounded sense of duty to obey the commands of institutions they deem rightful because of the source not the content. Since legitimacy involves internalising the moral value that they should obey the police because they're the police and obey the law because it's the law, it operates as a '... reservoir of loyalty on which leaders can draw, giving them the discretionary authority they require to govern effectively' (Tyler, 2006a: 26).

\section{SETTING THE SCENE \#2: AN OVERVIEW OF LEGITIMACY RESEARCH}

Over the past decade or so the literature has expanded rapidly across the world and can, broadly speaking, be divided into three categories:

1. Tests of procedural justice theory applied to the police using single city or national samples;

2. Cross-national studies examining levels of police legitimacy across countries; and

3. Assessments of the sources and consequences of legal legitimacy. 
First, tests of procedural justice theory using single country or single city samples tend to dominate the literature. Figure 1 provides an overview. On the left-hand side is the direct and indirect contact that citizens have with authority figures. Procedural justice theory posits that what is central to these encounters is whether the authority figures treat citizens in a fair and respectful way, make neutral and unbiased decisions, display trustworthy motives, and allow the citizen a 'voice' in their interactions (e.g. let them tell 'their side of the story'). Direct and indirect experiences then influence people's beliefs about how legal officials tend to act, specifically whether police officers (for example) generally act in ways that are procedurally fair, distributively fair, lawful and effective in the fight against crime (views that are no doubt also shaped by the broader cultural and media landscape). Crucially, people draw on these judgements when thinking about the legitimacy of the institution that officers represent. Supportive evidence for PJT has accumulated impressively in the US over the years (Tyler, 1990; Tyler \& Huo, 2002; Sunshine \& Tyler, 2003; Tyler \& Wakslak, 2004; Tyler \& Fagan, 2008; Tyler et al. 2010; Tyler et al., 2015; Tyler \& Trinkner, forthcoming) and since this pioneering work, tests of procedural justice theory have been conducted in countries across the world, including Australia (Murphy \& Cherney, 2012), Israel (Jonathan-Zamir \& Weisburd, 2013), UK (Huq et al. 2017), Ghana (2009), South Africa (Bradford et al. 2014), Pakistan (Jackson et al. 2014), Hong Kong (Cheng, 2015), Japan (Tsushima \& Hamai, 2015), China (Sun et al., 2017) and Trinidad \& Tobago (Kochel, 2012). Broadly speaking, this body of work supports the idea that there are, in any given society, certain core norms and values that determine how legal authorities should wield their authority, and when officials are seen to respect those norms and values, this generates institutional normativity among the general populace, and legitimacy motivates willing compliance and cooperation.

Figure 1: An overview of PJT

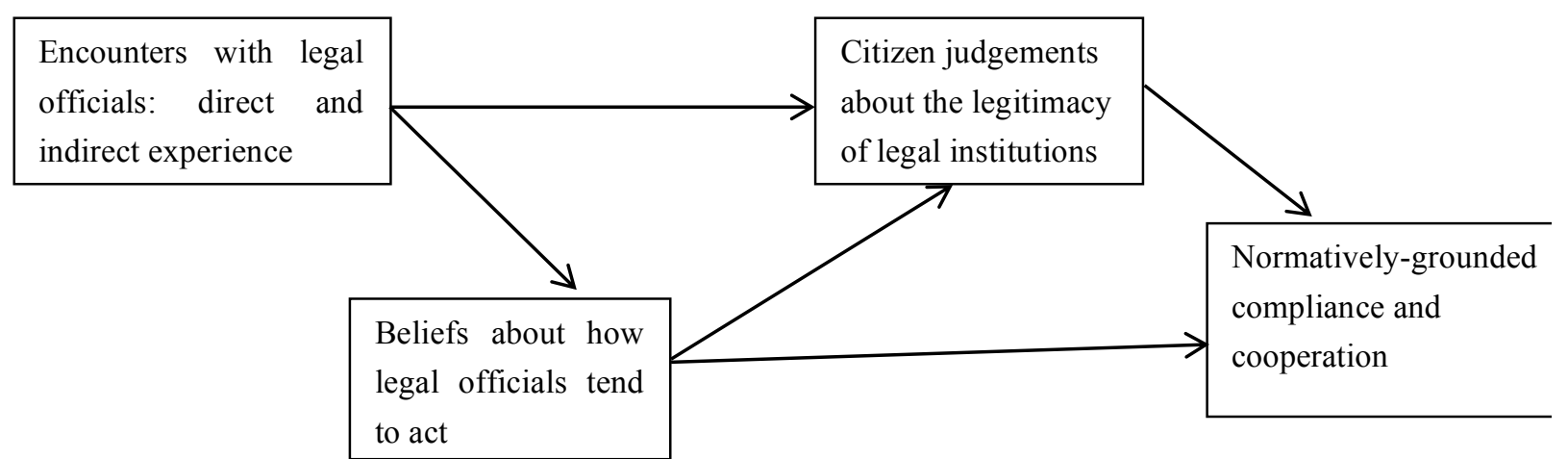

Second, the last few years have also seen a small number of cross-national studies of police legitimacy. Drawing on data from Round 5 of the European Social 
Survey (covering 27 countries), Hough et al. (2013) found that police legitimacy was highest in countries like Denmark, France, Sweden, Finland, Germany, Switzerland and Ireland, and lowest in countries like Estonia, Poland, Russian Federation, Bulgaria, Cyprus and Israel. Drawing on data from the Afrobarometer (covering 29 African countries), Boateng (2017) found that trust in the police (treated as a measure of legitimacy) was highest in Senegal, Niger, Namibia, Malawi, Burundi and Burkina Faso, and lowest in Nigeria, Kenya, Liberia and Sierra Leone. Using a similar indicator, this time fielded in the World Values Survey, Boateng \& Buckner (2017) found that confidence in the police was highest in Qatar, Uzbekistan and Jordan, and lowest in Pakistan, Armenia, Russia and Yemen. ${ }^{1}$

Third, legal legitimacy has received less attention (most of the work has been done in the US, Australia and UK). The focus of these studies tends to be on the role that legal legitimacy plays in explaining variation in self-reported past offending behaviour and self-reported future willingness to comply with the law, typically in the context of so-called 'everyday crimes', i.e. those less serious infractions that the general public are (a) more likely to engage in and (b) more likely to honestly report in an interview situation. The main goal of this work is to assess whether legitimacy predicts compliance, adjusting for people's instrumental motivations to comply (specifically, perceptual deterrence, i.e. their perceptions of the risk of being caught and punished). Some studies also adjust for people's beliefs about the morality of the illegal behaviours (this helps to isolate the content-independent influence of legitimacy).

Before turning to the literature on police and legal legitimacy in more detail, it is important to note that a defining feature of the literature is the ongoing debate about the nature of legitimacy (see Hawdon, 2008; Jackson et al. 2011; Bottoms \& Tankebe, 2012: Tankebe, 2013; Tyler \& Jackson, 2013, 2014; Jackson \& Gau, 2015; Tankebe et al., 2016; Hamm et al. 2017). Disagreement is not about what is being measured: there is a good deal of consensus about what legitimacy means as an abstract concept. Most scholars take the view that legitimacy exists when citizens (a) regard a legal institution as having a valid claim to exercise power and (b) feel a moral duty to obey the rules and commands that emanate from that institution (Tyler, 2006a, 2006b). The disagreement is about how it should be measured. And as I outline in the following pages, the lack of clarity and consistency is holding back the development of a properly comparative cross-national analysis.

\footnotetext{
${ }^{1}$ Using multi-level modelling, Boateng (2017) found that the key predictors of trust in the police were satisfaction with democracy, urban/rural locality, employment status and age (at the individual level) and 'peacefulness' and level of democracy (at the national level). Boateng \& Buckner (2017) found that key predictors at the individual level included media exposure, fear of crime and terrorism, marriage and employment status, and education. At the country level, key predictors included levels of democracy, 'peacefulness' and press freedom.
} 


\section{POLICE LEGITIMACY: INTERNATIONAL PERSPECTIVES}

This section turns to the rapidly expanding and increasingly international body of work on police legitimacy. To stress the problem of comparability, I organise the review according to the five main methodological approaches that scholars have taken to measuring police legitimacy:

1. single indicator of trust or confidence in the police;

2. one dimension, using either a scale of 'duty to obey' or a scale of 'institutional trust';

3. one dimension, combining 'duty to obey' and 'institutional trust' (sometimes including other constructs, such as affective bonds and motivational postures);

4. two dimensions, either differentiating between 'duty to obey' and 'institutional trust', or differentiating between 'duty to obey' and 'normative alignment'; and

5. four dimensions, differentiating between 'procedural justice', 'distributive justice', 'effectiveness' and 'lawfulness'.

Two recent cross-national studies, one in Africa (Boateng, 2017) and the other in Asia (Boateng \& Buckner, 2017), are good examples of the first approach. From a conceptual standpoint both papers define legitimacy as a normatively grounded sense of willingness to obey police commands, with Boateng (2017: 3) describing how 'individuals defer to and obey police commands because they respect and accept the police institution as an authority to make decisions' and Boateng \& Buckner (2017: 3) noting that 'To gain legitimacy in an empirical sense, one must genuinely believe that an institution has the authority to regulate his/her conduct.' Yet, both use a single indicator of legitimacy (trust in the police in Africa and confidence in the policing in Asia) to operationalise the construct in the empirical work. They jettison the notion of voluntary deference to authority from the operational definition and they treat trust and confidence as proxies for the perceived right to power.

The second approach uses an index to measure police legitimacy, using either a scale of voluntary deference to their authority, or a scale of institutional trust and confidence in the police. Research participants in Sun et al.'s (2017) Chinese single city study were asked whether they felt that they should obey the directives of police (even if they did not understand why officers gave those directives or do not agree with their reasons) and obey the decisions of police officers (because it is the right and proper thing to do). A similar approach was taken in Pryce et al.'s (2016) study of Ghanaian immigrants in Virginia (US) and Karakus's (2017) Istanbul study. Other work has put institutional trust centre-stage. For example, in a study of police-citizen relations in Israel, Metcalfe et al.(2017) argued that: 
'If the police behave in ways that align with citizens' expectationsthey perform their duties with the community's best interests in mind and can be trusted to accomplish their responsibilities effectively-they are viewed as a legitimate authority. Accordingly, we view police legitimacy as a normative attitude based on motive-based trust and confidence in the police.'

Their survey of mostly residents of Jerusalem tapped into sentiments such as 'the police can be trusted to make decisions that are right for the people in my neighbourhood' and 'I trust the leaders of the Israeli National Police to make decisions that are good for everyone.'

The third approach combines a number of related ideas in the definition of legitimacy. This is best illustrated by Sunshine \& Tyler's (2003) New York City study, which fused together notions of institutional trust (trust in the honesty and lawfulness of officers), confidence and pride in the police, and obligation to obey the police and law into one index. Other work by Tyler (e.g. Tyler, 2006a; 47) has stressed allegiance and support in the operational definition, involving not only a positive 'affective orientation' towards an institution, but also a positive 'general evaluation' of how authority figures behave. A similar approach was taken in a randomised controlled trial of procedural justice policing (the Queensland Community Engagement Trial, Mazerolle et al. 2013), which combined obligation to obey the police and law (again including legal cynicism measures), consistency between participants' own views and the law, and negative orientations toward the police. Indeed, populating notions of appropriateness and obligation in a single scale is common. A London-based study into young males from various black and minority ethnic groups asked respondents whether they felt a moral obligation to obey the police and whether they thought that the police was a normatively appropriate institution (Jackson et al. 2014). In a study set in Nigeria, Akinlabi (2015: 10) combined measures of obligation, trust and 'whether public perceives the police as wielding their authority against them or to their interest' to explore police legitimacy in this West African state.

The fourth approach defines legitimacy along two dimensions: one being right to rule judgements (e.g. institutional trust), the other being felt obligation to obey. Studies that have adopted a reflective approach to measurement have, almost without exception, found that legitimacy loads on two positively correlated underlying dimensions. For example, Reisig et al.'s (2007) national US study used exploratory factor analysis to test the dimensionality of legitimacy. They showed that trust in the police and obligation to obey should be treated as two separate constituent components of legitimacy, as did another US-based study (Wolfe et al., 2016: 11). In South Africa, Bradford et al. (2014) differentiated between obligation to obey and normative alignment, i.e. the sense in which authority figures act in ways aligned with established, shared, normative and ethical frameworks, and the same 
approach has been taken in a national survey of Japanese citizens (Tsushima \& Hamai, 2015), a survey of citizens of Lahore, Pakistan (Jackson et al. 2014), a US study (Hamm et al. 2017), two UK-based studies (Jackson et al. 2012a, 2012b), and Round 5 of the European Social Survey (Hough et al. 2013).

The fifth (and final) approach to measuring police legitimacy drops the notion of willing deference to authority from the concept and breaks down right to power judgements into the four dimensions of procedural justice, distributive justice, lawfulness and effectiveness (Bottoms \& Tankebe, 2012; Tankebe, 2013; Tankebe et al. 2015). This approach assumes that procedural justice, distributive justice, effectiveness and lawfulness are the four key societal values that dictate how authorities should behave in a given social, political and legal context (if they are to be seen as legitimate). If one buys this account in a given context, then (a) there is no need to make it an empirical question whether this is, in fact, true or not, and (b) one can skip measuring some kind of overarching right to rule legitimacy (because, one assumes, assessments of the trustworthiness of the police to be procedurally fair, distributively fair, effective and lawful entirely capture the content of normativity). Tankebe and colleagues also argue that people can feel an obligation to obey the police for reasons other than legitimacy, so we should not include a normatively grounded sense of civic duty to obey within the legitimacy concept. People could respond positively to standard legitimacy indicators, not because they feel some kind of normatively grounded moral duty to obey, but because they feel a prudential and/or instrumental form of obligation. Indeed, it may even be possible that citizens who experience their relationship to the police as a 'power relationship, pure and simple, with no element of right' (Bottoms \& Tankebe, 2012: 126) could report something that we, as researchers, wrongly interpret as legitimacy.

\section{TOWARDS A COMPARATIVE LITERATURE ON LEVELS OF POLICE LEGITIMACY ACORSS THE WORLD}

Let us turn to the task of developing a cross-national literature. Imagine, for one moment, that you are interested in documenting national levels of police legitimacy in countries across the world - the literature certainly spans a good deal of contexts, and a good place to start would be the cross-national work set in Africa (Boateng, 2017), Asia (Boateng \& Buckner, 2017) and Europe (Kaariainen, 2007; Hough et al. 2013). But while reading this work, you might be struck by how difficult it is to properly compare studies. Only a single measure of trust (in the 28 African countries) or confidence (in the 29 Asian countries) was used. The European Social Survey routinely fields a similar question to its respondent (see Kaariainen's (2007) analysis of differences in levels of trust in the police across 16 European countries). You could pool the data from these three surveys and paint a country-level picture across Asia, Africa and Europe, since pretty much the same measure was used. 
But you might, on reflection, find this a little unsatisfying. Why does Kaariainen (2007) call this trust in the police while Boateng (2017) calls this police legitimacy? The criminological literature is full of single city or country studies that use survey indicators like 'how confident are you in the police?' or 'how much do you trust the police,' and scholars variously treat these as measures of 'confidence in policing' (in Belgium, Van Craen, 2003; in China, Sun et al., 2013; and in Australia, Zahnow et al. 2017), 'trust in the police' (in Belgium, Van Craen \& Skogan, 2015; and in Hungary, Boda \& Medve-Balint, 2017) or 'police legitimacy' (in Turkey, Karakus, 2017; and in Nigeria, Akinlabi, 2017). Should we include all these studies when reviewing the legitimacy literature, even though the researchers involved do not seem to agree on what they are measuring? Moreover, the other major cross-national assessment is Round 5 of the European Social Survey, which fielded multiple indicators of duty to obey and normative alignment with the police (Jackson, et al. 2011). Should those data points be included? If so, how?

\section{TOWARDS A COMPARATIVE CROSS-NATIONAL LITERATURE ON THE ANTECEDENTS OF POLICE LEGITIMACY}

In addition, imagine that you want to examine whether the sources of police legitimacy vary from one context to the next. Do the normative criteria of legitimacy that people apply to the police depend to some degree on context? It seems, looking across the available evidence, that process matters most when police power is exercised (Kochel et al. 2013; Jonathan-Zamir \& Weisburd, 2013; Hough et al. 2013a, 2013b; Cheng, 2015, 2016; Murphy et al. 2016; Sun et al. 2017; Brouwer et al. 2017). The majority of studies in the US, Australia, UK, continental Europe, Israel and further afield have showed that when citizens believe that officers generally act in procedurally fair ways they also tend to view the institution as morally valid (whether measured via trust/confidence or normative alignment) and to voluntarily defer to the authority that legitimacy lends officers. Assessments of the effectiveness of the police or whether police allocate outcomes (such as arrests, citations, protection and service) fairly are typically much less important predictors of legitimacy. On this account, what underpins the normative justification of police power most keenly is the importance of treating those they protect and regulate with dignity and respect, behaving in neutral, unbiased ways, showing trustworthy motives and a willingness to help citizens, and allowing citizens voice and agency in interactions (Trinkner \& Tyler, 2016; Trinkner et al. 2017).

It is, however, difficult to make precise comparisons across multiple jurisdictions because some studies treat legitimacy as trust, different studies take different approaches to defining and measuring procedural justice (some studies even include trustworthy motives in the procedural justice concept), and not all studies include a relatively complete set of assessments of how officers behave. However, a handful of studies set in the US, UK, South Africa, Japan and across the European Union have (a) defined and measured legitimacy in the same way, (b) 
included the same set of assessments of how officers behave, and (c) defined and measured these legitimacy judgements in the same way. All these studies specified legitimacy along two dimensions (normative alignment and duty to obey) and in both the UK and the US, procedural justice was a stronger predictor of both aspects of police legitimacy than effectiveness (Jackson et al. 2012a; Tyler \& Jackson, 2014). Looking across Europe, the same pattern held in most of the countries (Hough et al. 2013). Procedural justice was a stronger predictor of both normative alignment and duty to obey, compared to effectiveness and distributive justice.

The story in Japan is a little different, however. While procedural justice was a stronger predictor of normative alignment than effectiveness, for duty to obey it was effectiveness that was more important (Tsushima \& Hamai, 2015). What about countries that have (a) high levels of crime and (b) legal institutions that have not yet shown their ability to secure a bare-minimum ability to provide security to citizens and be free from corruption? Thus far, in such contexts, the evidence points towards the idea that that police effectiveness is a stronger predictor of legitimacy than procedural justice. In South African work, Bradford et al. (2014) argued that normative judgements about fair process may, to some degree, be crowded out by concerns about police effectiveness and corruption, the sheer scale of the crime problem and the association of the police with a historically oppressive and underperforming state. Work in Ghana (Tankebe, 2009) and Pakistan (Jackson et al. 2014) supports this notion.

It is important that the literature expands the country focus, pays more attention to methodological equivalence, and avoids conflating the antecedents of legitimacy with legitimacy itself, particularly concerning the right to rule part of the concept (Gau, 2011; Reisig et al. 2007; White et al. 2015). For example, some measures of trust and confidence (treated as legitimacy) come a little close to the motive-based trust component of procedural justice, e.g. 'the police care about the well-being of everyone they deal with' (Tyler \& Fagan, 2008). In a study of the attitudes and experiences of terrorism-related policing among London-based Muslims (Huq et al. 2011), one of the measures of legitimacy was 'you trust the police to make decisions that are good for everyone when they are investigating and prosecuting terrorism' and three of the measures of procedural justice referred to 'applying the law consistently to everyone', 'taking into account the needs and concerns of the people they deal with' and 'considering people's views when deciding what to do.' When the measures of different concepts overlap, this risks artificially inflating the observed correlation.

Consider the approach of Tankebe and colleagues. Legitimacy is measured along four dimensions - procedural justice, distributive justice, effectiveness and lawfulness - but according to procedural justice theory, it is an empirical question whether, when forming legitimacy judgements, citizens focus most keenly on the procedural fairness of officers, the distributive fairness of officers, the effectiveness of officers and so forth. The approach of Tankebe and colleagues assumes - by 
definition - that citizens judge the legitimacy on the basis of the procedural and distributive justice of officer behaviour, whether officers act lawfully, and whether they are effective in dealing with crime. If one used this approach in cross-national research, it would not be an empirical question whether people assess police legitimacy in different ways in different societal settings; the researcher a priori assumes the normative preconditions of legitimacy in a given context. If the focus is cross-national, then the researcher is, by definition, assuming that the normative preconditions of legitimacy are exactly the same in different social, political and legal contexts.

\section{TOWARDS A COMPARATIVE CROSS-NATIONAL LITERATURE ON THE CONSEQUENCES OF POLICE LEGITIMACY}

What about the consequences of police legitimacy? It is fair to say that the literature has focused on people's willingness to cooperate with the police, without too much emphasis placed on isolating exactly the psychological mechanism(s) at play. In Cherney \& Murphy's (2013) investigation into the views and experiences of Arabicspeaking people in Australia, trust in the police was a key predictor of willingness to help the police in both general crime control and specific counter-terrorism activities. This suggests that these research participants were more willing to proactively help the efforts of the police when they believed that the police have the right intentions and can be trusted to act in ways that take into account the views and interests of the local community. It does, indeed, seem plausible that shared interests and social bonds partly drive public cooperation with the police.

What about the motivational role of voluntary deference to police authority? Drawing on data from a sample of adolescents in Jamaica, Reisig \& Lloyd (2008) found that obligation was not a significant predictor of willingness to cooperate with the police. Kochel et al.'s (2013) Trinidad \& Tobago-set study also found obligation to be a weak (and not statistically significant) predictor of people's willingness to report a crime to the police. Intriguingly, the fact that procedural justice was more important than obligation suggests that people may be more willing to come forward with information to the police when they trust that officers will treat them with respect and dignity and make fair and just decisions. Indeed, it is not entirely clear why duty to obey would motivate proactive cooperation. In the context of compliance with the police, the mechanism would be more obvious; people internalise the overarching moral value that it is the right and proper thing to defer to the decisions and orders of officers. Deference shapes reactive behaviour. Why would duty to obey encourage more proactive behaviours like going out of one's way to report a crime and give information to the police?

Most studies into legitimacy-cooperation relations treat legitimacy as a combination of appropriateness and obligation. For example, Sunshine \& Tyler (2003) found that people tended to report being willing to cooperate when they viewed the police as a morally valid institution that is entitled to be obeyed (no 
matter their ethnic group). The same was found in Tyler \& Fagan's (2008) longitudinal study that was set in the same city. White et al. (2015) interviewed individuals who had been arrested for a variety of different crimes in Arizona, showing that people who felt a normatively-grounded sense of support of - and deference towards - the police tended to report being willing to report a crime to the police (for instance). This generalised across offender type, e.g. violent, property or drug crime. In Mazerolle et al.'s (2013) RCT of process-based policing in Queensland, Australia, legitimacy (similarly defined) was a strong predictor of willingness to cooperate with the police, and in Murphy's (2013) work, also set in Australia, legitimacy was a stronger predictor of willingness to report a crime to the police among young people compared to adults.

However, Huq et al.'s (2011) study of Muslims living in London found no relationship between legitimacy and cooperation. A feature of this work was its focus on police investigation and prosecution of terrorism, with legitimacy measured using standard duty to obey indicators, plus two items about the appropriateness of police behaviour regarding the policing of terrorism in their own community. And willingness to cooperate with the police addressing, among other things, encouraging members of their own community to help the police fight terrorism and reporting to the police a person distributing material expressing support for al Qaeda. A central finding of their study was that fairness of policy formation (i.e. where government involved the community in the design of policy) and the procedural fairness of the officers' implementation policy were key predictors of willingness to cooperate, but legitimacy was not. Of the predictors of legitimacy judgements, people who felt that police unfairly targeted their community tended to see the police as less legitimate, compared to those who felt that police were not so intrusive. The national study of Japanese citizens mentioned earlier in this review also found that legitimacy was unrelated to cooperation (Tsushima and Hamai, 2015). Neither duty to obey nor normative alignment with the police predicted general willingness to report a crime and give information to officers. Interestingly, there was little variation in people's willingness to cooperate; most research participants expressed a strong willingness. The two authors offer a number of fascinating potential explanations, including the notion that legal citizenship and duty to obey do not translate so neatly into Japanese society, and the idea that Japan's low crime levels are less to do with the police, and more to do with the strong, culturally bound sources of order, informal sanctioning and surveillance that lie outside the ambit of the criminal justice system.

When studies have differentiated between trust in the police and obligation to obey, they have tended to find that trust is a more important predictor of cooperation than obligation (e.g. Reisig et al., 2007 and Dirikx and van Den Bulck, 2014), and when studies have differentiated between normative alignment and obligation to obey, they have tended to find that normative alignment is more important than obligation (e.g. Jackson et al., 2012b). Of particular note are three 
pieces of work. Tyler \& Jackson's (2014) US-based study pitted different elements of legitimacy against each other, with all three predicting cooperation (normative alignment was a stronger predictor than trust, and trust was a stronger predictor than obligation). Van Damme et al.'s (2013) Swedish based study placed concepts in a particular order, where trust in police procedural fairness predicted normative alignment, normative alignment predicted obligation to obey, and obligation to obey predicted willingness to cooperate with the police. Hamm et al. (2017) found that normative alignment was a more important predictor of willingness to cooperate than obligation to obey, with the willingness to be vulnerable also significant (captured using measures like 'I am generally comfortable being vulnerable to the judgement of the police in my community' and 'I would be comfortable letting the police in my community handle a specific situation that was important to me').

In summary, one facet of the legitimacy concept tends to be more strongly related to cooperation than the other facet (obligation to obey). People who trust the police and/or feel normatively aligned with the police tend to report a greater willingness to go out of their way to help the police fight crime, compared to people who feel an obligation to obey the police. There is also an emerging line of research that links police legitimacy to public attitudes towards violence, whether it be police use of violence or citizen use of violence to achieve certain social and political goals (Jackson et al. 2013; Bradford et al. 2017; Gerber \& Jackson, 2017). But it is difficult to properly compile a comparative body of evidence because, as a whole, studies lack comparability. We need a concerted commitment to methodological equivalence going forward.

\section{LEGAL LEGITIMACY}

Turning now to the legitimacy of the law, (i) what does legal legitimacy and normatively-grounded law-abidingness means in people's everyday lives? And (ii) what is the evidence linking legal legitimacy to legal compliance (for discussion about causality see Nagin \& Telep, 2017a, 2017b, and Tyler, 2017)? From a conceptual standpoint, legal legitimacy tends to be defined as an active and willing acceptance of the right of the law to dictate appropriate behaviour. Just like police legitimacy, this form of voluntary deference to authority is assumed to be grounded in the recognition of the normativity of the justice system more broadly. There are three main approaches to measuring legal legitimacy:

1. combining legal legitimacy with police legitimacy in various different forms;

2. one dimension, using a scale of 'legal cynicism', 'obligation to obey' or 'normative alignment'; and

3. two dimensions: 'obligation to obey' and 'normative alignment'. 
An example of the first approach is Tyler et al.'s (2015) US-based study, in which a single composite index brought together normative alignment with the law (e.g. 'the law does not protect your interests'), normative alignment with the police (e.g. 'the police usually act in ways consistent with your own ideas about what is right and wrong'), obligation to obey the law (e.g. 'all laws should be strictly obeyed') and obligation to obey the police (e.g. 'the police in your community are legitimate authorities so you should do what they tell you to do'). Other studies have taken a similar approach. As with police legitimacy, this is a trend that can be traced back to Tyler's (1990) foundational book Why People Obey the Law. For instance, Penner et al.'s (2014) longitudinal study of just under 100 young people on probation in British Columbia (Canada) combined measures of obligation to obey the law with measures of support for the police and courts.

Another classic study, this time of legal cynicism (an example of the second approach), is Sampson \& Bartusch's (1998) Chicago-based work. To capture 'the sense in which laws or rules are not considered binding in the existential, present lives of respondents', measures like 'laws were made to be broken' aimed to assess the "ratification of acting in ways that are "outside" of law and social norms (p. 786). Kirk \& Papachristos (2011: 1197) broadened out the concept, defining legal cynicism as a 'frame through which individuals interpret the functioning and viability of the law and its agents, especially law enforcement'. To tap into the sentiment that the law is just, legitimate and responsive, they combined the 'laws are made to be broken' survey indicator with two judgements of police effectiveness ('the police are not doing a good job in preventing crime in the neighbourhood' and 'the police are not able to maintain order on the streets and sidewalks in the neighbourhood'). Another approach to measuring legal cynicism stresses the belief that legal norms are unjust, drawing on the idea that legal cynicism arises through what Nivette et al. (2015: 4) call

'....individual and collective experiences of disadvantage and injustice. As bonds to social institutions weaken, legal norms lose their "bindingness" and this may be replaced by attitudes that justify contempt of legal rules, the self-centred pursuit of one's goals, and distrust in the police.'

Papachristos et al. (2012) used a similar index that included measures like 'people should obey the law even if it goes against what they think is right' with measures like 'the law represents the values of the people in power, rather than the values of people like me'. In an Australian study, Murphy et al. (1997) used measures like 'the laws that the police enforce are consistent with the views of Australians' to capture normative alignment with the law.

An example of the third approach is Trinkner et al.'s (forthcoming) US-based study, which defined legal legitimacy along two dimensions. Normative alignment was operationalised as the extent to which people felt that the laws that the police 
generally enforce in their communities aligned with their own moral values and that the enforcement of those laws helped maintain order and cooperation in their community. Example measures are 'your own feelings about what is right and wrong usually agree with the laws by the police and the courts' and 'obeying the law ultimately benefits everyone in the community'. Duty to obey was defined and measured in the normal way, using for instance measures like 'sometimes doing the right thing means breaking the law.'

Before turning to the empirical evidence on the link between legitimacy and compliance, it is important to position legitimacy within Bottoms's (2002) four categories for the explanation of compliance with authority in general, and with the criminal law in particular:

1. prudential or self-interested calculations about the potential costs and benefits of breaking the law, taking into account the risks and costs of punishment;

2. the impact of obstructive strategies, such as locking up offenders to prevent their reoffending, and locking up the targets of criminal attention, literally or metaphorically;

3. normative considerations about the 'rights and wrongs' of non-compliance; and

4. habit.

These categories help us be clear about the difference between obeying the law and acting consistently with the law (Schauer, 2015). Acting consistently with the law means conforming with the law for reasons independent of the law, i.e. “...engaging in the same behaviour we would have engaged in even if no laws regulating it existed" (Schauer, 2015: 6). By contrast, legitimacy forms part of people's normative considerations about the 'rights and wrongs' of non-compliance, stepping in when moral values, social norms and habit in some sense 'fail.' Legitimacy provides a motive to obey the law rather than a motive to act consistently with the law. Legitimacy means treating an order or rule as 'superseding and replacing one's own judgement' (Bottoms \& Tankebe, 2012: 135), whereby people internalise a general moral obligation to obey the law because it's the law. Crucially, this is assumed to be through the associate obligations, positional duties and affective bonds that legitimate power structures generate and maintain.

DOES THE LEGITIMACY OF THE LAW PREDICT COMPLIANCE WITH THE LAW?

To empirically isolate the content-independent motivational force of legal legitimacy, criminological studies tend to adjust for key predictors of legal compliance and offending behaviour. In Tyler's (1990) seminal Chicago-based study, for instance, legitimacy (combining felt obligation to obey the law and 
support for the police and courts) was a statistically significant predictor of legal compliance, adjusting for perceptions of the risk of getting caught, the likelihood of peer disapproval, and the morality of the various crimes they were being asked about. The focus was on various low-level crimes like driving while intoxicated, shoplifting inexpensive items, and disturbing neighbours with noise. The empirical link between legitimacy and compliance held in both an analysis of data from the first of two waves of the panel study, and an analysis of data from both waves (using legitimacy at time-point one to predict legal compliance at time-point two). The same type of low-level crimes was addressed in Sunshine \& Tyler's (2003) New York City study. Legitimacy was again a significant predictor of compliance, this time adjusting for perceived risk of getting caught and perceptions of police fairness and performance.

A more recent US study differentiated between minor crimes (e.g. breaking traffic laws) and major crimes (e.g. buying stolen goods), and treated legitimacy as a three-dimensional construct - obligation, trust and confidence, and normative alignment (Tyler \& Jackson, 2014). Of these three different facets, obligation was the most important predictor of minor and major compliance, adjusting for the perceived risk of getting caught. Reisig et al. (2007) similarly treated legitimacy as a multi-dimensional construct (distinguishing between trust in the police and obligation to obey the police and law) but this time it was trust in the police that was a significant predictor of everyday legal compliance, not obligation to obey. Interestingly, both studies used a national sample of US citizens.

Moving across the Atlantic, a nationally representative sample survey of England and Wales found that felt moral duty to obey the law predicted legal compliance, adjusting for the perceived risk of getting caught, the immorality of the criminal acts, obligation to obey the police, and normative alignment with the police (Jackson et al., 2012b). Again, the focus was on low-level crimes - i.e. the type of activities that could plausibly be carried out by "those who think of themselves as respectable citizens, and who would definitely reject the labels of "criminals" and "crime" for themselves and their action' (Karstedt and Farrall 2006: 1011). Legitimacy was linked back to positive and negative encounters with police officers, and the argument made was that procedural justice strengthens the sense that police respect the societal norms that determine how they should behave towards citizens, which in turn strengthens one's commitment to the societal norms dictating how citizens should behave in relation to the law.

Some studies have addressed the link between legitimacy and compliance among known offender populations. An Australian panel study into tax fraud showed a link between legitimacy and offending behaviour, adjusting for perceived risk and personal morality (Murphy et al., 2016). A study of "active offenders" as part of the Chicago Gun Project found that individuals with social networks that were saturated with gang members tended to have more negative views towards the law and legal authorities, and that legitimacy was a significant negative predictor of 
carrying a gun (but not of fighting), adjusting for an index of deterrence (Papachristos et al., 2012). Also focusing on known offenders, researchers have drawn upon data in the Pathways to Desistance Study set in Pennsylvania and Arizona. Augustyn (2015) used a scale of 22 illegal activities, some of which are relatively serious (e.g. taking something from someone by force with a weapon and breaking into a building to steal something), finding that legal cynicism was a significant predictor of legal compliance among individuals who had been arrested when they were thirteen years of age or older. Notably, Augustyn adjusted for an unusually comprehensive range of factors, including trust in the police, perceptions of procedural justice among police and judges, criminal history, personal rewards of crime, punishment costs, and perceived certainty of punishment. Kaiser \& Reisig (2017) fitted a series of multi-level longitudinal count models to the same source of data, finding that legal cynicism predicted changing levels of criminal offending, while the legitimacy of the police and courts (specifically, support for the police and courts) explained between-individual variation.

Penner et al.'s (2014) longitudinal study of youth on probation in British Columbia, Canada, found that prior experience of procedural justice within the juvenile justice system predicted both self-reported offending and official offending records, but only when that experience was within the past three months. In other words, the effect seemed to wane. Legitimacy - obligation to obey the law and support for the police and courts - did not mediate this effect, however, nor was it associated with offending behaviour. Cavanagh \& Cauffman (2015) focused on first-time male offenders aged 13-17 in California, Louisiana and Pennsylvania, drawing on data from the Crossroads longitudinal study. The novel contribution was to consider the legitimacy judgements of both the mother and the son. The young people included in the study had just experienced their first encounter with the criminal justice system, and their legitimacy judgements predicted self-reported and officially recorded offending. Moreover, mothers' legitimacy judgements predicted sons' legitimacy judgements, suggesting not only intergenerational attitude transmission, but also a potential influencing effect.

Nivette et al. (2015) called upon data from a prospective longitudinal study of a cohort of children in various primary schools in Zurich, Switzerland. Focusing on the waves in which children were 13 and 15, the goal was to examine the factors that predict legal cynicism. Of the various constructs included in the model - such as bonds to social institutions (commitment to school, feelings of alienation from society, and parental involvement in their lives), generalised trust, self-control, negative experiences with legal authorities, and the morality of rule transgressions - they found that involvement in delinquent activities was the strongest predictor. The authors suggest a possible neutralisation function: namely that 'adolescents may adopt legal cynicism as a technique to justify wrongdoing.'

One of the few studies linking legitimacy to legal compliance outside of North America, Australia and Europe is that of Lui \& Lui (2017). Drawing on data from a convenience sample of high school students in Guangzhou, China, these authors 
examined the factors linked to a broad range of offending behaviour, including vandalism, shoplifting, burglary, weapon carrying, drug dealing, and animal abuse. Details are a little hazy, but the mean of the compliance index was 0.83 , suggesting that $83 \%$ of the sample said that they had not committed any of the crimes. The authors found that police distributive fairness and support for the police were significant predictors of compliance; felt obligation to obey the police was not an important predictor; and legal legitimacy was not addressed in the study.

Finally, Trinkner et al. (2017) found that duty to obey was a significant negative predictor of past criminal behaviour (e.g. buying something that might be stolen, taking something from a store without paying for it, and illegally disposing of rubbish or litter), adjusting for normative alignment with the law (as well as the judgements about the risk of sanction and the morality of buying stolen goods, shoplifting, and dumping rubbish and so forth). Normative alignment with the law was defined as the belief that the laws that are generally enforced in one's community align with one's sense of right and wrong and that members of one's community should obey the law to help maintain a mutually beneficial scheme of social cooperation. The argument is that duty to obey may play a contentindependent role in explaining variation in compliance with the law.

\section{CLOSING REMARKS}

In this review, I have argued that the remarkable burst of international enthusiasm for examining the nature and significance of the legitimacy of legal authorities has outpaced attention to equivalence, rigour of measurement and theoretical ambition. Legitimacy has been measured in a variety of different ways, and the overarching lack of measurement equivalence means that it is difficult to properly compare studies. Some scholars have treated legitimacy as a uni-dimensional construct, others as a multi-dimensional construct. Some scholars have differentiated between the police, courts and law, others have bundled them together. There has been a connected failure to develop a comparable body of cross-national research that places legitimacy within its broader theoretical context. In particular, the fuzziness of the operational definitions has hindered our ability to understand the content of legitimation and the influence of legitimacy. Some approaches have conflated legitimation with legitimacy, and it is often not clear why legitimacy motivates cooperation and compliance (if indeed it does) in a particular context. For a formal, comparative cross-national body of evidence to develop, we need some kind of agreed basis on which to define and measure concepts in comparable (but locally appropriate) ways in different national settings. We also need to model legitimacy within a comparably ambitious framework that maximises definitional clarity and analytical power. Only then can this exciting and rapidly expanding body of international research reach its full potential. 
By way of contribution, I close with what I think are some of the more promising ways forward. Starting with police legitimacy, it is important to consider both right to rule judgements (the normative appropriateness of an institution) and obligation to obey (the right of a legal authority to dictate appropriate behaviour). Right to rule judgements should be overarching (they should not assume the value content of legitimation, i.e. the criteria that citizens apply when judging the legitimacy of a particular institution) and obligation to obey measures should be phrased in ways that clearly reference a sense of truly free consent towards a normatively appropriate institution. Given the occasional tendency of institutional trust measures to overlap in content with procedural justice, and given the lack of clarity regarding (a) how it motivates and (b) whether the motivational force chimes with standard definitions of the legitimacy concept, I would recommend approaching it through the lens of normative alignment. Standard measures of normative alignment, fielded across Europe and in the US, South Africa and Japan, tap into an overarching sense of appropriateness. A key part of normative alignment is that the belief that the police act in ways that align with societal standards strengthens the corresponding belief among citizens that they, too, should act appropriately - if they act properly, I'll act properly. The study of Hamm et al. (2017) is illustrative because they measured people's willingness to be vulnerable (part of the trust concept) and found that normative alignment predicted willingness to cooperate, adjusting for willingness to be vulnerable, and studies like this, which hone in on the motivational character of police legitimacy, are to be welcomed, as are studies that broaden out the range of potential predicates of police legitimacy. For instance, Huq et al. (2017) found that procedural justice and bounded authority (respecting the limits of one's rightful authority) predicted police legitimacy, but distributive justice and perceptions of surveillance activities did not (effectiveness predicted duty to obey but not normative alignment).

For legal legitimacy, one important thing to clarify in future research is the definition, specifically whether normative alignment and obligation to obey comprise one or two dimensions of the construct. This would, among other things, help isolate the mechanisms at play in the link between legal legitimacy and legal compliance (assuming there is robust dependence between these two factors in a given social, political and legal context). What, in addition, are the key predictors of legal legitimacy? Trinkner et al. (forthcoming) found that a good deal of variation in normative alignment with the law was explained by police legitimacy and assessments of officer behaviour, but much less variation in obligation to obey the law was explained by the same factors. We need more work on this issue. It is also important to use innovative measures to address the issue of social desirability. Randomised response techniques (like the item count technique, see Kuha \& Jackson, 2014) may help improve the reliability of self-reported offending measures. Finally, studies should endeavour to measure other motivations to act consistency with the law and obey the law - most obviously, personal moral, social norms (e.g. disapproval of others) and perceptual deterrence. We can explore the role that 
legitimacy plays - for instance, obligation to obey may strengthen people's willingness to obey the law while normative alignment may strengthen people's willingness to act in ways that are consistent with the law.

Finally, a constant theme throughout this review is the role that methodological equivalence plays in building up a robust body of comparable evidence. Needless to say, studies in countries across the world should gravitate towards some common method - only then can we start to properly build up a powerful comparative analysis of police-citizen authority relations across the world.

\section{REFERENCES}

Akinlabi, O. M. (2017). Young people, procedural justice and police legitimacy in Nigeria. Policing and Society, 27(4), 419-438.

Augustyn, M. B. (2015). The (ir) relevance of procedural justice in the pathways to crime. Law and Human Behavior, 39(4), 388.

Boateng, F. D. (2017). Police legitimacy in Africa: a multilevel multinational analysis. Policing and Society, 1-16.

Boateng, F. D., and Buckner, Z. N. (2017). Police legitimacy in Asia: findings from a multilevel hierarchical non-linear analysis. Policing and Society, 1-18. 
Boda, Z., and Medve-Bálint, G. (2017). How perceptions and personal contact matter: The individual-level determinants of trust in police in Hungary. Policing and society, 27(7), 732-749.

Bottoms, A. (2002) 'Compliance and Community Penalties' (pp. 87-116), in Bottoms, A., Gelsthorpe, L., and Rex, S., Community Penalties: Change and Challenges. Cullompton: Willan.

Bottoms, A., and Tankebe, J. (2012). Beyond procedural justice: A dialogic approach to legitimacy in criminal justice. Journal of Criminal Law and Criminology, 102, 119_ 170 .

Bradford, B., Huq A., Jackson, J. and Roberts, B. (2014). What price fairness when security is at stake? Police legitimacy in South Africa. Regulation and Governance, $8,246-268$.

Bradford, B., Milani, J. and Jackson, J. (2017). 'Identity, Legitimacy and "Making Sense" of Police Use of Force', Policing: An International Journal of Police Strategies and Management, 40, 3, 614-627.

Brouwer, J., Van Der Woude, M., and Van Der Leun, J. (2017). Border policing, procedural justice and belonging: the legitimacy of (cr) immigration controls in border areas. British Journal of Criminology, doi: 10.1093/bjc/azx050

Caldeira, G. A., and Gibson, J. L. (1995). The legitimacy of the Court of Justice in the European Union: Models of institutional support. American Political Science Review, 89(2), 356-376.

Cavanagh, C., and Cauffman, E. (2015). Viewing law and order: Mothers' and sons' justice system legitimacy attitudes and juvenile recidivism. Psychology, Public Policy, and Law, 21(4), 432.

Cheng, K. K. Y. (2015). Prosecutorial procedural justice and public legitimacy in Hong Kong. British Journal of Criminology, 57(1), 94-111.

Cheng, K. K. Y. (2016). Legitimacy in a Postcolonial Legal System: Public Perception of Procedural Justice and Moral Alignment Toward the Courts in Hong Kong. Law and Social Inquiry, doi: 10.1111/1si.12253.

Cherney, A., and Murphy, K. (2013). Policing terrorism with procedural justice: The role of police legitimacy and law legitimacy. Australian and New Zealand journal of criminology, 46(3), 403-421.

Dirikx, A., and Van den Bulck, J. (2013). Media use and the process-based model for police cooperation: An integrative approach towards explaining adolescents' intentions to cooperate with the police. British Journal of Criminology, 54(2), 344-365.

Duguid, M.M. and Thomas-Hunt, M.C. (2014) Condoning Stereotyping?: How Awareness of Stereotyping Prevalence Impacts Expression of Stereotypes. Journal of Applied Psychology: 343-359.

Gau, J. M. (2011). The convergent and discriminant validity of procedural justice and police legitimacy: An empirical test of core theoretical propositions. Journal of Criminal Justice, 39, 489-498.

Gerber, M. and Jackson, J. (2017). Justifying Violence: Legitimacy, Ideology and 
Public Support for Police Use of Force', Psychology, Crime and Law, 23, 1, 79-95, doi: 10.1080/1068316X.2016.1220556.

Gibson, J. L., Caldeira, G. A., and Spence, L. K. (2003). Measuring attitudes toward the United States supreme court. American Journal of Political Science, 47(2), 354367.

Hamm, J. A., Trinkner, R., and Carr, J. D. (2017). Fair Process, Trust, and Cooperation: Moving Toward an Integrated Framework of Police Legitimacy. Criminal Justice and Behavior, 0093854817710058.

Hawdon, J. (2008). Legitimacy, trust, social capital, and policing styles: A theoretical statement. Police Quarterly, 11, 182-201. doi: 10.1177/1098611107311852

Hinsch, Wilfried. 2010. Justice, legitimacy, and constitutional rights, Critical Review of International Social and Political Philosophy, 13: 39-54.

Hough, M., Jackson, J. and Bradford, B. (2013). Legitimacy, trust and compliance: an empirical test of procedural justice theory using the European Social Survey. In J. Tankebe and A. Liebling (Eds.), Legitimacy and Criminal Justice: An International Exploration (pp. 326-352). Oxford: Oxford University Press.

Huq, A. Z., Tyler, T. R., and Schulhofer, S. J. (2011). Mechanisms for eliciting cooperation in counterterrorism policing: A study of British Muslims. Journal of Empirical Legal Studies, 8, 728-761.

Huq, A., Jackson, J.and Trinkner, R. (2017). Legitimating practices: Revisiting the predicates of police legitimacy. British Journal of Criminology, 57(5), 1101-1122.

Jackson, J. (2015). On the dual motivational force of legitimate authority, in Bornstein, B. H. and Tomkins, A. J. (eds.) Cooperation and compliance with authority: The role of institutional trust. 62nd Nebraska Symposium on Motivation. New York: Springer, pp. 145-166.

Jackson, J., Asif, M., Bradford, B. and Zakar, M. Z. (2014). Corruption and police legitimacy in Lahore, Pakistan. British Journal of Criminology, 54, 1067-1088.

Jackson, J., Bradford, B., Hough, M., Kuha, J., Stares, S. R., Widdop, S., ... and Galev, T. (2011). Developing European indicators of trust in justice. European Journal of Criminology, 8, 267-285.

Jackson, J., Bradford, B., Hough, M., Myhill, A., Quinton, P., and Tyler, T. R. (2012a). Why do people comply with the law? Legitimacy and the influence of legal institutions. British Journal of Criminology, 52, 1051-1071.

Jackson, J., Bradford, B., Stanko, E. A. and Hohl, K. (2012b), Just Authority? Trust in the Police in England and $W$ ales. Routledge.

Jackson, Jonathan, and Jacinta M. Gau. 2015. Carving up concepts? Differentiating between trust and legitimacy in public attitudes towards legal authority. In Interdisciplinary Perspectives on Trust: Towards Theoretical and Methodological Integration, 
eds. Ellie Shockley, Tess M.S. Neal, Lisa M. PytlikZillig, and Brian H. Bornstein, New York: Springer.

Jackson, J., Huq, A., Bradford, B. and Tyler, T. R. (2013). 'Monopolizing Force? Police Legitimacy and Public Attitudes towards the Acceptability of Violence', Psychology, Public Policy and Law, 19, 4, 479-497, doi: 10.1037/a0033852.

Johnson, Devon, Edward R. Maguire, and Joseph B. Kuhns. 2014. Public perceptions of the legitimacy of the law and legal authorities: Evidence from the Caribbean, Law and Society Review 48:947-978.

Jonathan-Zamir, T., and Harpaz, A. (2014). Police understanding of the foundations of their legitimacy in the eyes of the public: The case of commanding officers in the Israel national police, British Journal of Criminology, 54, 3, 469-489.

Justice, B. and Meares, T. (2014). How the criminal justice system educates citizens. The Annals of the American Academy of Political and Social Science, 651(1), 159-177.

Justice, B. and Meares, T. (2014). How the criminal justice system educates citizens. The Annals of the American Academy of Political and Social Science, 651(1), 159-177.

Kääriäinen, J. T. (2007). Trust in the police in 16 European countries: A multilevel analysis. European Journal of Criminology, 4(4), 409-435.

Karakus, O. (2017). Instrumental and Normative Pathways to Legitimacy and Public Cooperation with the Police in Turkey : Considering Perceived Neighborhood Characteristics and Local Government Performance. Justice Quarterly, 34(1): 2554.

Karstedt, S., and Farrall, S. (2006), 'The Moral Economy of Everyday Crime: Markets, Consumers and Citizens', British Journal of Criminology, 46: 1011-1103.

Kirk, D. S., and Papachristos, A. V. (2011). Cultural mechanisms and the persistence of neighborhood violence. American Journal of Sociology, 116(4), 1190-1233.

Kochel, T. (2012). Can police legitimacy promote collective efficacy?." Justice Quarterly 29, no. 3 (2012): 384-419.

Kochel, T. R. (2017). Applying police legitimacy, cooperation, and collective security hypotheses to explain collective efficacy and violence across neighbourhoods. International Journal of Comparative and Applied Criminal Justice, 1-20.

Kochel, T., Parks, R. and Mastrofski, S. (2013). Examining police effectiveness as a precursor to legitimacy and cooperation with police. Justice Quarterly, 30, 895925.

Kuha, J. and Jackson, J. (2014). 'The Item Count Method for Sensitive Survey Questions: Modelling Criminal Behaviour', Journal of the Royal Statistical Society: Series C (Applied Statistics), 63, 2, 321-342, doi: 10.1111/rssc.12018.

Liebling, A. (2004). Prisons and their Moral Performance. Oxford: Oxford University Press.

Madon, N. S., Murphy, K., and Cherney, A. (2016). Promoting Community Collaboration in Counterterrorism: Do Social Identities and Perceptions of Legitimacy Mediate Reactions to Procedural Justice Policing?. British Journal of Criminology, azw053.

Mazerolle, L., Antrobus, E., Bennett, S., and Tyler, T. R. (2013). Shaping citizen 
perceptions of police legitimacy: A randomized field trial of procedural justice. Criminology, 51, 33-63.

McAdams, R. H. (2015). The Expressive Powers of Law: Theories and Limits. Harvard University Press.

Meares, T. (2017). Policing and Procedural Justice: Shaping Citizens' Identities to Increase Democratic Participation. Northwestern University Law Review, 111(6), 1525-1536.

Meško, G., and Tankebe, J. (Eds.). (2014). Trust and Legitimacy in Criminal Justice: European perspectives. Springer.

Metcalfe, C., and Hodge, O. (2017). Empowering the police to fight terrorism in Israel. Criminology and Criminal Justice, 1748895817739664.

Murphy, K. (2015). Does procedural justice matter to youth? Comparing adults' and youths' willingness to collaborate with police. Policing and Society, 25(1), 53-76.

Murphy, K., and Cherney, A. (2011). Understanding cooperation with police in a diverse society. British Journal of Criminology 52:181-201.

Murphy, K., Bradford, B. and Jackson, J. (2016). Motivating compliance behavior among offenders: Procedural justice or deterrence? Criminal Justice and Behavior 43:102-118.

Murphy, T. (2017). Challenging the 'invariance' thesis: procedural justice policing and the moderating influence of trust on citizens' obligation to obey police. Journal of Experimental Criminology, doi: 10.1007/s11292-017-9298-y

Nadler, J. (2017). Expressive Law, Social Norms, and Social Groups. Law and Social Inquiry, 42(1), 60-75.

Nagin, D. S. (2013). Deterrence: A review of the evidence by a criminologist for economists. Annual Review of Economics, 5(1), 83-105.

Nagin, D. S., and Telep, C. W. (2017a). Procedural justice and legal compliance." Annual Review of Law and Social Science.

Nagin, D. S., and Telep, C. W. (2017b). Reponse to "Procedural Justice and Policing: A Rush to Judgment?". Annual Review of Law and Social Science.

Nivette, A. E., Eisner, M., Malti, T., and Ribeaud, D. (2015). The social and developmental antecedents of legal cynicism. Journal of Research in Crime and Delinquency, 52(2), 270-298.

Oberwittler, D., and Roché, S. (Eds.). (2017). Police-Citizen Relations Across the World: Comparing sources and contexts of trust and legitimacy. Routledge.

Papachristos, A. V., Meares, T. L., and Fagan, J. (2012). Why do criminals obey the law? The influence of legitimacy and social networks on active gun offenders. Journal of Criminal Law and Criminology, 102, 397-440.

Pardo, I. (2000). Morals of Legitimacy: Between Agency and System. New York: Berghahn Books.

Peršak, N. (2016). Legitimacy and trust in criminal law, policy and justice: Norms, procedures, outcomes. Routledge. 
President's Task Force on 21st Century Policing. 2015. Final Report of the President's Task Force on 21st Century Policing. Washington, DC: Office of Community Oriented Policing Services. Accessed 8/8/16 from http://www.cops.usdoj.gov/pdf/taskforce/taskforce_finalreport.pdf

Pryce, D. K. (2016). Ghanaian immigrants' experiences with and perceptions of US police: A qualitative study. Criminal Justice Review, 41(4), 469-487.

PytlikZillig, L. M. and KJimbrough, C. D. (2015). 'Consensus on Conceptualizations and Definitions of Trust: Are We There Yet?', in Shockley, E., Neal, T. M. S., PytlikZillig, L. and Bornstein, B. (eds.) Interdisciplinary Perspectives on Trust: Towards Theoretical and Methodological Integration. New York: Springer.

Reiner, R. (2010) The Politics of the Police. Oxford: Oxford University Press.

Reisig, M. D. and Lloyd, C. (2009). Procedural justice, police legitimacy, and helping the police fight crime: Results from a survey of Jamaican adolescents, Police Quarterly, 12, 42-62.

Reisig, M. D., Bratton, J. and Gertz, M. G. (2007). The construct validity and refinement of process-based policing measures. Criminal Justice and Behavior, 34, 1005-1027.

Reisig, M. D., Wolfe, S. E., and Holtfreter, K. (2011). Legal cynicism, legitimacy, and criminal offending: The nonconfounding effect of low self-control. Criminal Justice and Behavior, 38(12), 1265-1279.

Sampson, R. J. and Bartusch, D. J. (1998). Legal cynicism and (subcultural?) tolerance of deviance: The neighborhood context of racial differences. Law and Society Review, 32, 777-804.

Sargeant, E., Murphy, K., and Cherney, A. (2014). Ethnicity, trust and cooperation with police: Testing the dominance of the process-based model. European Journal of Criminology, 11(4), 500-524.

Schauer, F. (2015). The Force of Law. Harvard University Press.

Stoutland, S. (2001). The multiple dimensions of trust in resident/police relations in Boston. Journal of Research in Crime and Delinquency, 38, 226-256. doi:10.1177/0022427801038003002

Sun, I. Y., Wu, Y., and Hu, R. (2013). Public assessments of the police in rural and urban China: A theoretical extension and empirical investigation. British Journal of Criminology, 53(4), 643-664.

Sun, I.Y., Wu, Y., Hu, R. and Farmer, A.K. (2017). Procedural justice, legitimacy, and public cooperation with police: Does Western wisdom hold in China? Journal of Research in Crime and Delinquency, 54(4), 454-478.

Sunshine, J., and Tyler, T. R. (2003). The role of procedural justice and legitimacy in public support for policing. Law and Society Review, 37, 513-548.

Tankebe, J. (2009). Public cooperation with the police in Ghana: Does procedural fairness matter? Criminology, 47:1265-1293.

Tankebe, J. (2013). Viewing things differently: The dimensions of public perceptions of legitimacy. Criminology, 51, 103-135. 
Tankebe, J., and Liebling, A. (2013). Legitimacy and Criminal Justice: An International Exploration. OUP Oxford.

Tankebe, J., Reisig, M. D., and Wang, X. (2016). A multidimensional model of police legitimacy: A cross-cultural assessment. Law and Human Behavior, 40(1), 11.

Trinkner, R., and Tyler, T. R. (2016). Legal socialization: Coercion vs. consent in an era of mistrust. Annual Review of Law and Social Science, 12, 417-439.

Trinkner, R., Jackson, J., and Tyler, T. (forthcoming). Bounded Authority: Expanding 'Appropriate' Police Behavior Beyond Procedural Justice. Law and Human Behavior.

Tsushima, M., and Hamai, K. (2015). Public cooperation with the police in Japan: Testing the legitimacy model. Journal of Contemporary Criminal Justice, 31(2), 212228.

Turner, J.C. (1984) "Social Identification and Psychological Group Formation." In H. J. Tajfel, (ed.) The Social Dimension: European Developments in Social Psychology. Cambridge, UK: Cambridge University of Press, pp. 518-536.

Tyler, T. R. (1989). The psychology of procedural justice: A test of the group-value model. Journal of Personality and Social Psychology, 57, 830-838.

Tyler, T. R. (1990). Why People Obey the Law [first edition]. New Haven: Yale University Press.

Tyler, T. R. (1994). Psychological models of the justice motive. Journal of Personality and Social Psychology, 67, 850-863.

Tyler, T. R. (1997). The psychology of legitimacy. Personality and Social Psychology Review, 1, 323-344.

Tyler, T. R. (2003). Procedural justice, legitimacy, and the effective rule of law. In M. Tonry (Ed.), Crime and justice: A review of research (vol. 30, pp. 431-505). Chicago: University of Chicago Press.

Tyler, T. R. (2004). Enhancing police legitimacy. The Annals of the American Academy, 593, 84-99.

Tyler, T. R. (2005). Policing in black and white: Ethnic group differences in trust and confidence in the police. Police quarterly, 8(3), 322-342.

Tyler, T. R. (2006a). Why People Obey the Law [second edition]. New Haven: Yale University Press.

Tyler, T. R. (2006b). Psychological perspectives on legitimacy and legitimation. Annual Review of Psychology, 57, 375-400.

Tyler, T. R. (2011). Trust and legitimacy: Policing in the USA and Europe. European Journal of Criminology, 8, 254-266.

Tyler, T. R. (2017). Procedural Justice and Policing: A Rush to Judgment?. Annual Review of Law and Social Science.

Tyler, T. R. (Ed.). (2007). Legitimacy and Criminal Justice: An International Perspective. Russell Sage Foundation.

Tyler, T. R. and Jackson, J. (2013). Future challenges in the study of legitimacy and criminal justice. In J. Tankebe and A. Liebling (Eds.), Legitimacy and Criminal 
Justice: An International Exploration (pp. 83-104). Oxford: Oxford University Press.

Tyler, T. R., and Fagan, J. (2008). Why do people cooperate with the police? Ohio State Journal of Criminal Law, 6, 231-275.

Tyler, T. R., and Huo, Y. J. (2002). Trust in the law: Encouraging public cooperation with the police and courts. New York: Russell-Sage Foundation.

Tyler, T. R., and Jackson, J. (2014). Popular legitimacy and the exercise of legal authority: Motivating compliance, cooperation and engagement. Psychology, Public Policy and Law, 20, 78-95.

Tyler, T. R., and Trinkner, R. (in press). Why children follow rules: Legal socialization and the development of legitimacy. New York: Oxford University Press.

Tyler, T. R., and Wakslak, C. J. (2004). Profiling and police legitimacy: Procedural justice, attributions of motive, and acceptance of police authority. Criminology, 42(2), 253-282.

Tyler, T. R., Jackson, J. and Mentovich, A. (2015). The consequences of being an object of suspicion: Potential pitfalls of proactive police contact. Journal of Empirical Legal Studies, 12:602-636.

Tyler, T. R., Schulhofer, S. J., and Huq, A. Z. (2010). Legitimacy and deterrence effects in counter-terrorism policing: A study of Muslim Americans. Law and Society Review, 44, 365-401.

Tyler, T.R. (1988). What is procedural justice?: Criteria used by citizens to assess the fairness of legal procedures. Law and Society Review, 22, 103-135.

Van Craen, M. (2013). Explaining majority and minority trust in the police. Justice Quarterly, 30(6), 1042-1067.

Van Craen, M., and Skogan, W. G. (2015). Trust in the Belgian police: The importance of responsiveness. European journal of criminology, 12(2), 129-150.

Van Damme, A., Pauwels, L., and Svensson, R. (2015). Why do Swedes cooperate with the police? A SEM analysis of Tyler's procedural justice model. European journal on criminal policy and research, 21 (1), 15-33.

White, M. D., Mulvey, P. and Dario, L. M. (2016). Arrestees' perceptions of the police: Exploring procedural justice, legitimacy, and willingness to cooperate with police across offender types. Criminal Justice and Behavior, 43:343-364.

Wolfe, S. E. (2011). The effect of low self-control on perceived police legitimacy. Journal of Criminal Justice, 39(1), 67-74.

Wolfe, S. E., Nix, J., Kaminski, R. and Rojek, J. (2016). Is the effect of procedural justice on police legitimacy invariant? Testing the generality of procedural justice and competing antecedents of legitimacy. Journal of Quantitative Criminology, 32:253-282.

Zahnow, R., Mazerolle, L., Wickes, R. and Corcoran, J. (2017) Living near violence: how proximity to violence shapes perceptions of police effectiveness and confidence in police. Journal of Environmental Psychology, 53 138-144. doi:10.1016/j.jenvp.2017.07.007 
Jonathan Jackson

Norms, Normativity and the Legitimacy of Justice Institutions 